\title{
Endoscopically Assisted Root Splitting (EARS): Method and First Results
}

\author{
Sección Radicular Endoscópicamente Asistida (SREA): Método y Primeros Resultados
}

Wilfried Engelke; Víctor Beltrán**; Ramón Fuentes** \& Oscar Decco**

ENGELKE, W.; BELTRÁN, V.; FUENTES, R. \& DECCO, O. Endoscopically Assisted Root Splitting (EARS): Method and First Results. Int. J. Odontostomat., 6(3):313-316, 2012.

ABSTRACT: The trauma of surrounding bone structures during exodontia represents a mayor clinical shortcoming of conventional oral surgery. An alternative minimal invasive technique is presented to support aesthetic rehabilitation by conservation of alveolar bone walls. Endoscopically assisted root splitting (EARS) is a new technique for root removal wothout ostectomy. EARS consists of enlargment of the root canal, longitudinal root splitting, inward mobilisation and removal of the fragments under endoscopic control. In 24 patients (11 m, $13 \mathrm{f}$ ), aged 18-66 years, 8 central incisors, 6 lateral incisor, 5 canines and 5 bicuspids were removed using EARS. Endoscopic observation revealed complete maintenance of the buccal wall at it's preoperative level, control radiographs showed no apical root remnants. EARS has revealed to be a valuable tool to avoid alveolar crest trauma during exodontia

KEY WORDS: Endoscopy; Extraction Socket, Socket Preservation.

\section{INTRODUCTION}

Tooth extraction although being a routine intervention still is associated with serious side effects including mechanical trauma of the surrounding alveolar bone and periodontal tissues. Irreversible loss of alveolar soft and hard tissue results, when in case of partial or complete ankylosis an osteotomy is performed.

The intraoperative trauma is one of the mayor factors determining the bone volume for later reconstruction with or without implants. Fig. 1 shows the impact which may be caused by conventional extraction on the maintenance of the alveolar bone contour: Alveolar bone lamellae are attached to the extracted tooth by local ankylosis and therefore lead to primary substantial bone loss which may exceed the amount of post extraction resorption by far.

In contemporary textbook theories (Reichardt, 1995), the main goal of exodontic surgery in case of given indication is the removal of the entire tooth irrespectively of collateral damage to the alveolar crest structures. Recently a shift in paradigms can be observed towards atraumatic surgical techniques in third molar surgery like odontosection (Genu et al., 2008; Arakeri et al., 2010; Ngeow, 2008), and partial removal of third molar crowns ( Landi et al., 2010). This also applies to tooth removal in the anterior aesthetic zone, where buccal bone loss has a very high impact on implant treatment outcome (Al Harbi, 2011). Kim et al. (2010) reported a comparative study with partially erupted third mandibular molars. The authors concluded, that a flapless procedure with tooth sectioning instead of conventional flap based removal resulted in lower postoperative morbidity. Different studies have shown, that large defects of the original buccal plate, which have occured due to periodontal disease or a traumatric extraction procedure do not heal completely, if a bone graft technique is not applied (Al Harbi, 2011; Araujo \& Lindhe, 2005).

With the improved insight into small blood filled intraoral cavities (Engelke, 2002; Beltrán et al., 2011a; Beltrán et al., 2011b; Beltrán et al., 2012) it has become possible to use the visual information to reduce the osseous trauma in case of tooth removal with the goal

\footnotetext{
Department of Maxillofacial Surgery, Georg August University Göttingen, Universitätsmedizin, Göttingen, Germany.

" Department of Integral Odontology, Faculty of Dentistry, Universidad de La Frontera, Temuco, Chile.

*** General Hospital of Diamante/ Entre Ríos, Universidad Nacional de Entre Ríos Fac. de Ingeniería, Oro Verde, Entre Ríos, Argentina. This Study was supported by grants from Degradable Solution, Suiza.
} 


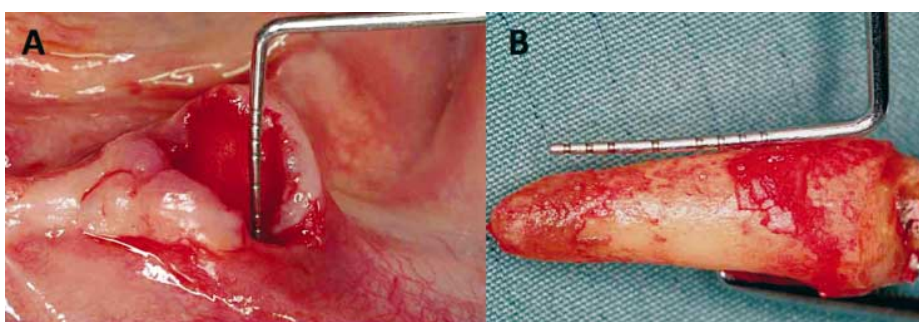

Fig. 1A: Impact caused by conventional extraction on the maintenance of the alveolar bone contour, 1B: Alveolar bone lamellae are attached to the extracted tooth by local ankylosis.

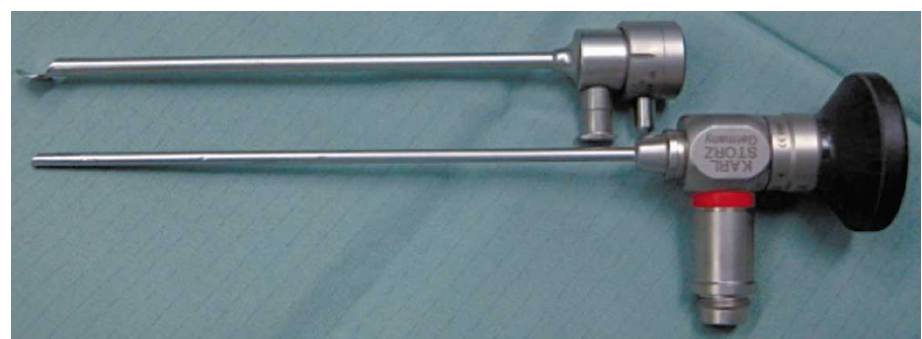

Fig. 2. Support endoscope type Engelke, Karl Storz, Tuttlingen, Germany.

to keep the alveolar trauma as low as possible. This was applied by Engelke et al. (2011) for removal of fully impacted third mandibular molars via an occlusal approach. They showed, that the buccal bone loss could be reduced to a mean of 2.1 $\mathrm{mm}$ in situations with complete retention. Similarly, Fuentes et al. (2012) reported the importance of support endoscopy in the removal of third mandibular molars to avoid inferior alveolar nerve damage and bone defect formation.

In the present report we describe the endoscopically assisted root splitting (EARS) technique which may serve as a basic tool for atraumatic tooth removal. As many other dental specialties make progress in their conservative approaches, EARS represents a conservative approach which does follow this trend in oral surgery.

\section{MATERIAL AND METHOD}

Surgical procedure: EARS is performed under local anesthesia (4\% articaine with 1: 100000 epinephrine). The surgeon works in a 9 o clock position observing the operation site on a video screen via a Storz Hopkins support endoscope (30 degree view angle, $2.7 \mathrm{~mm}$ diameter, Karl Storz Tuttlingen, Germany) (Fig 2). The support endoscope is placed adjacent to the surgical site using the spatula of the support tube for maintenance of distance (Engelke \& Capobianco 2004, Beltran et al., 2012). To obtain a precise view of the root anatomy, the crown is removed completely via transversal separation at the level of the gingiva.
RS (Longitudinal root splitting) is displayed in Fig. 3., RS starts with the identification of the root canal and subsequent enlargement of the canal at least to the apical third of the root (Fig. $3 A$ ). Enlargement is assisted by Gates burs and/ or Lindemann straight burs in a low speed surgical handpiece (Fig. 3B). Using straight or angulated elevators, a longitudinal split of the root is performed without damaging the surrounding alveolar bone wall (Fig. 3C). The fragments are mobilized towards the center of the alveolous (implosion technique). They are removed subsequently if necessary under endoscopic control using small Bein elevators or a tissue forceps (Fig. 3D). If an apical root fragment is present following splitting, it can easily be identified endoscopically and removed separately with a Heidbrink elevator or a root forceps (Fig. 3E). If endoscopic inspection reveals, that a periapical granuloma or cyst is present, it can be removed under direct vision using small curettes ( Fig. 3F).

\section{RESULTS}

Endoscopically assisted RS was applied in 24 consecutive patients with informed consent, $11 \mathrm{~m}, 13 \mathrm{f}$, aged 18-66 years were operated on at the Dept. of Maxillofacial Surgery, GAU Göttingen, Germany, the Center for Oral Microsurgery, UFRO/ Temuco, Chile and at the dental treatment center of Bioimplants Laboratory at UNER/Entre Rios, Argentina. 8 central incisors 6 lateral incisors, 5 canines and 5 bicuspids were removed using RS. Endoscopic observation revealed complete mainenance of the buccal wall at it's preoperative level, control radiographs showed no apical root remnants.

\section{DISCUSSION}

The answer of oral surgery on modern day conservative dentistry when focused on tooth extraction can be but selective removal of those tissue components which are a risk of infection, cause pain, do not fulfil functional or esthetic tasks. Compared to conventional extraction procedures, the RS technique allows to protect the surrounding alveolous especially in the esthetic zone similar to the reports of Yalcin et al. 


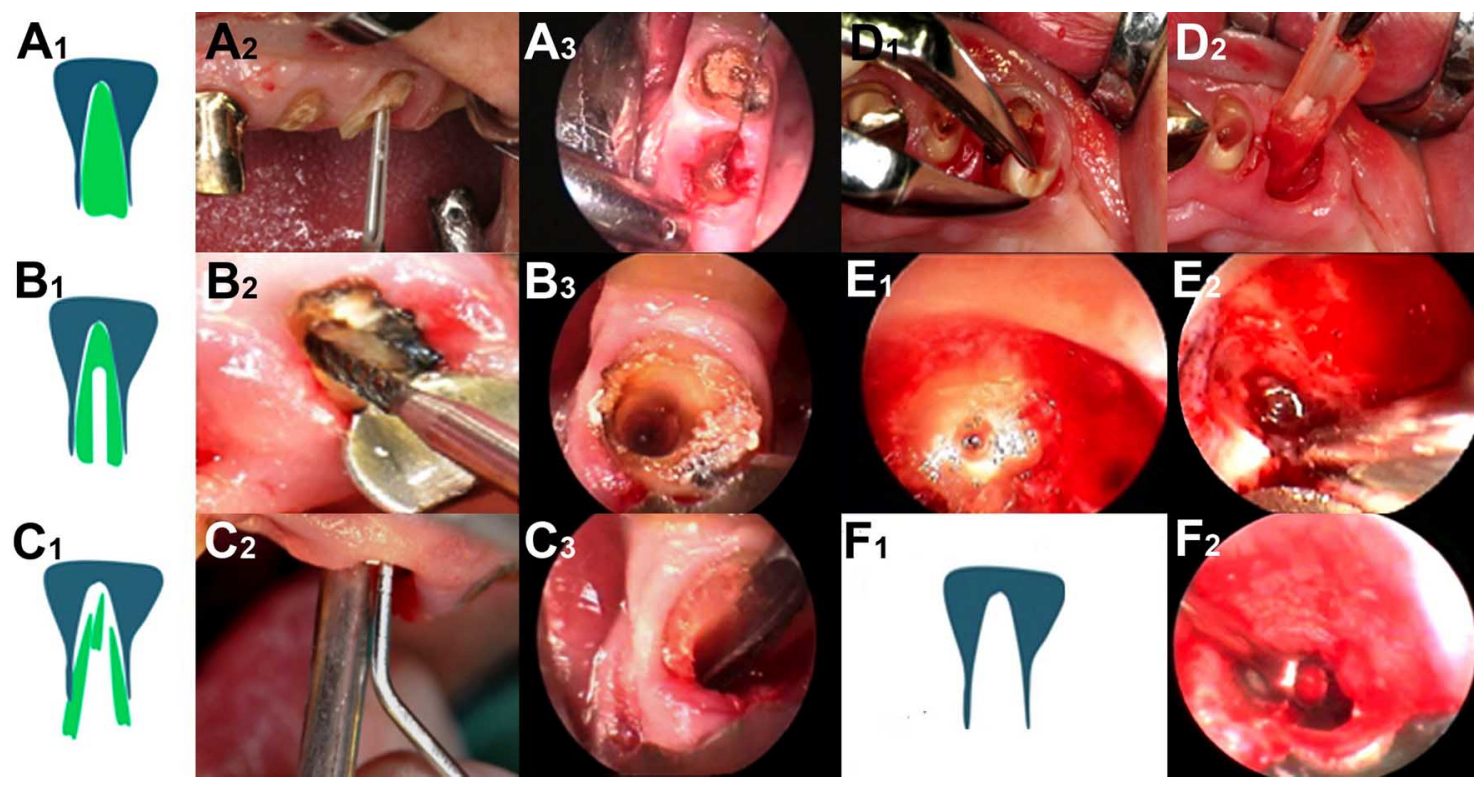

Fig. 3. A-F: ES Type 1: Root splitting: 3A: Identification of the root canal 3B: Enlargement of the root canal 3C: root splitting using straight Bein elevators 3D: removal of fragments 3E: removal of the root tip 3F: Curettage of the apical area.

2009, Al Harbi, (2012). The splitting of the root makes it possible to remove the fragments without pressure against the surrounding tissues, if suffficient space inside the central part of the root is provided (Engelke et al. 2011), the absence of osseous and periosteal trauma may have importance when reduction of pain and swelling of the surrounding tissues is intended as shown by Kim et al. (2010). This needs to be evaluated in a further study after having demonstrated the feasibiliy of the technique in general.

EARS can be comprised generally similar to the procedure proposed by Al Harbi (2012) for anterior teeth although in our report no implants were placed. The simultaneous placement of dental implants in case of reduced bone volume may be a treatment of high risk. Combination with the socket preservation using various materials is possible and can be recommended according to the degree of intraopertive defect of the alveolous. In case of difficult root anatomy, a simple exraction of the root fragments is impossible, therefore the the procedure must be changed from a conventional vision to endoscopic evaluation and if required to endoscopically assisted surgery. RS technique implies, that compared to conventional extraction no surgical manipulation of the alveolar walls, no force transmission towards neighbouring teeth, no incision and no osteotomy is necessary. It currently can be recommended for roots without complete ankylosis which may or may not exhibit periodontal disease, single tooth extraction with at least mobility grade 1 .
Undoubtfully, all inflammatory or cystic tissue during tooth removal has to be eliminated in any exodontia as a main goal of threatment, in particularat the apical aspect of the socket. Considering that the open flap procedure always causes postoperative discomfort of patients undergoing exodontia. Kim et al. ( 2010) showed, that flapless removal of third molares significantly reduced postoperative swelling, reduced use of analgesics and duration of pain.

The limited experience of this technical report gives evidence, that the height of the buccal wall by means of $\mathrm{RS}$ can be maintained This is in accordance with previous reports of Engelke et al. (2011) in inferior third molars. Nevertheless as a disadvantage it shall be mentioned, that the time required for RS compared with osteotomy at present seems to be larger. Within the 24 interventions, no serious inflammatory complications could be observed. In contrast, the majority of persons treated this way, reported no hematoma and no swelling after RS.

The technique of Yalcin et al. (2009) mainly meets the conditions of our Type 1 Root sectioning: Enlargement of the root canal in conjunction withremoval of the surrounding lamellae. Yalcin et al. included into their study only cases with at least $4 \mathrm{~mm}$ bone beyond the apex, this apparently wasnecesary to avoid dislocation of the root into the maxillary sinus or risk of erve damage when remoing the apical tip with rotating insruments. 
The technical report presented here is part of an ongoing study in this field. Terfore we would like to encourage workgroups interested in this field to contact us to participate in a broader application of this promising approach to low trauma exodontia.

CONCLUSION. Root sectioning is a valuable aid to remove destructed teeth in the anterior esthetic zone without damage of the alveolar walls. Endoscopic control is essential for precise identification and removal of apical root fragments.

ENGELKE, W.; BELTRÁN, V.; FUENTES, R. \& DECCO, O. Sección radicular endoscópicamente asistida (SREA): método y primeros resultados. Int. J. Odontostomat., 6(3):313-316, 2012.

RESUMEN: El trauma de las estructuras circundantes al hueso durante la exodoncia representa una de las principales deficiencias de la cirugía cirugía oral convencional. Se presenta una técnica alternativa mínimamente invasiva para apoyar la rehabilitación estética mediante la conservación de las paredes alveolares óseas. La sección radicular endoscópicamente asistida (SREA) es una nueva técnica para la eliminación de raíz sin osteotomía. La SREA consiste en la ampliación del canal de la raíz, división longitudinal de la raíz, movilización hacia el interior y eliminación de los fragmentos bajo control endoscópico. En 24 pacientes (11 hombres y 13 mujeres), con edades comprendidas entre 18-66 años, 8 incisivos centrales, 6 incisivos laterales, 5 caninos y 5 premolares fueron eliminadas mediante SREA. La observación endoscópica reveló la mantención completa de la pared ósea bucal a nivel preoperatorios, y las radiografías de control no mostraron restos radiculares apicales. SREA se muestra como una valiosa herramienta para evitar el trauma de la cresta alveolar durante la exodoncia.

PALABRAS CLAVE: endoscopía, extracción, alvéolo, preservación del alvéolo.

\section{REFERENCES}

Arakeri, G. \& Arali, V. Tooth section technique and pain upon elevation in third molar removal. Int. J. Oral Maxillofac. Surg., 39:98, 2010.

Araujo, M.G. \& Lindhe, J. Dimensional ridge alterations following tooth extraction. An experimental study in the dog. J. Clin. Periodontol., 32:212-8, 2005.

Beltrán, V.; Fuentes, R.; Engelke, W.; Marchesani, F. \& Flores, M. Location of Maxillary Sinus Septum through an Endoscopic Approach. Report ofa Case and Review of the Literature. Int. J. Morphol., 29(2):636-43, 2011 a.

Beltrán,, V.; Cantin, M.; Fuentes, R. \& Engelke, W. Bilateral Presence of Mandibular Incisive Canal. An Anatomical Structure with Clinical Relevance. Int. J. Morphol., 29(2):5439, 2011b.
Beltrán, V.; Fuentes, R. \& Engelke, W. Endoscopic visualization of anatomic structures as a support tool in oral surgery and implantology. J. Oral Maxillofac. Surg., 70(1):e1-6, 2012.

Engelke, W. In situ examination of implant sites with support immersion endoscopy. Int. J. Oral Maxillofac. Implants. 17(5):703-6, 2002.

Engelke, W. \& Capobianco, M. Endoskopische Verfahren in der oralen Implantologie. Z Zahnärztl Implantol., 20:248-56, 2004.

Engelke, W.; Bierbaum, J. \& Choi, E.J. Die mikrochirurgische Entfernung unterer dritter Molaren über einen okklusalen Zugang Dtsch Zahnärztl.,66:415-423, 2011.

Fuentes, R.; Beltrán, V.; Cantín, M. \& Engelke, W. Remoción de terceros molares mandibulares con asistencia endoscópica. Nota técnica de un nuevo procedimiento quirúrgico para prevenir lesiones del NAl y formación de defectos óseos. Rev. Clin. Periodoncia Implantol. Rehabil. Oral. 5(2): 83-86, 2012.

Genú, P.R. \& Vasconcelos, B.C. Influence of the tooth section technique in alveolar nerve damage after surgery of impacted lower third molars. Int. J. Oral Maxillofac. Surg., 37:923, 2008.

Kim, H.R.; Choi, B.H.; Engelke, W.; Serano, D.; Feng, X. \& Mo, D.Y. A comparative study on the extractions of partially impacted mandibular third molars with or without buccal flapa prospective study. J. Oral Maxillofac. Surg., 69:966-70, 2011.

Landi, L.; Manicone, P. F.; Piccinelli, S. \& et al: A novel surgical approach to impacted mandibular third molars to reduce the risk of paresthesia: a case series. J. Oral Maxillofac. Surg., 68:969, 2010.

Ngeow, W. C. Tooth section technique for wisdom teeth. Int. J. Oral Maxillofac. Surg., 38:908, 2009.

Reichardt, P. A.; Hausamen, J. E.; Machtens, E. \& Reuther, J. Dentoalveoläre Chirurgie in: Mund-Kiefer-Gesichtschirurgie, Springer Berlin, Heidelberg, 1995. pp 21-46.

Yalcin, S.; Aktas, I.; Emes, Y.; Kaya, G.; Aybar, B. \& Atalay B. A technique for atraumatic extraction of teeth before immediate implant placement using implant drills. Implant Dent., 18:46472, 2009.

Correspondence to:

Prof. Dr. Dr. Wilfried Engelke

Director of Research Group Oral Microsurgery

Dept. Maxillofacial Surgery

Georg August Universität

UMG Göttingen

Robert Koch Str. 40

Received: 11-06-2012

DEUSCHLAND

Accepted: 22-08-2012

Email: wengelke@med.uni-goettingen.de 